\author{
맥주박을 이용한 알코올 발효사료의 최적 발효조건 규명 \\ 김창혁·박병기·오상집·성경일·김현숙·홍병주·신종서 \\ 강원대학교 동물자원공동연구소
}

\title{
Determination of Optimum Fermentation Condition for Alcohol-Fermented Feeds with Wet Brewer's Grains
}

\author{
C. H. Kim, B. K. Park, S. J. Ohh, K. I. Sung, H. S. Kim, B. J. Hong and J. S. Shin \\ Institute of Animal Resources, Kangwon National University, Chuncheon 200-701, Korea
}

\begin{abstract}
To determine the optimum fermentation condition, the 50:50 feed mixture of both crushed corn and wet brewer's grain were anaerobically fermented at various conditions. Three supplementation levels $(0,2 \%$, and $5 \%)$ of molasses, five supplementation levels $(0,0.1 \%, 0.5 \%, 1.0 \%$, and $2.0 \%)$ of yeast and five different incubation temperatures $\left(4{ }^{\circ} \mathrm{C}\right.$, $10{ }^{\circ} \mathrm{C}, 30^{\circ} \mathrm{C}, 40{ }^{\circ} \mathrm{C}$ and $50{ }^{\circ} \mathrm{C}$ ) were tested to determine the optimum fermentation conditions. During fermentation, alcohol concentration, live yeast cell number (LYCN) and $\mathrm{pH}$ values of the mixture were analyzed. Alcohol concentrations of the fermented feed mixtures were proportionally increased with increasing level of molasses supplementation. After $24 \mathrm{hr}$ fermentation, alcohol concentrations at $0.1 \%, 0.5 \%, 1.0 \%$ and $2.0 \%$ of yeast supplementation was $1.9 \%, 2.4 \%, 3.1 \%$ and $3.1 \%$, respectively. These results indicate a proportional increase of alcohol concentration with the increasing supplementation of yeast $(\mathrm{P}<0.05)$ up to $1 \%$, thereafter showing plateau at $2 \%$ supplementation. $\mathrm{LYCN}$ was relatively high with more than $0.5 \%$ yeast supplementation, whereas the value was significantly $\operatorname{low}(\mathrm{P}<0.05)$ at $0.1 \%$ yeast supplementation. Alcohol production was significantly higher at $30{ }^{\circ} \mathrm{C}$ and $40{ }^{\circ} \mathrm{C}$ than other incubation temperatures $(\mathrm{P}<0.05)$, with the highest concentration at $30{ }^{\circ} \mathrm{C}$. $\mathrm{pH}$ was rapidly decreased until 24 hours of incubation with steeper decrease at lower temperatures $(\mathrm{P}<0.05)$. Based on there results, optimum fermentation conditions for the alcoholic-fermented feed production could be achieved with $5 \%$ supplementation of molasses, $1 \%$ supplementation of yeast, and $24 \mathrm{hr}$ long incubation at $30{ }^{\circ} \mathrm{C}$.

(Key words : Alcoholic fermented feeds, Rumen microbe, pH, Optimum fermentation condition, Yeast)
\end{abstract}

\section{I. 서 론}

최근, 유우 및 육우의 생산성을 개선시키기 위한 일환으로 이용되고 있는 미생물 첨가제인 Saccharomyces cerevisiae가 널리 사용되고 있다 (Wang 등, 2001; García 등, 2000; Sullivan과 Martin, 1999). 반추가축의 사료에 대한 yeast의 첨가는 섬유소 이용성 개선, 사료섭취량, 증체 량 및 사료효율을 개선하는 효과가 있으며
(Wang 등, 2001; Newbold 등, 1998, Wohlt 등, 1998; Williams 등, 1991; Fallon과 Harte, 1987; Panchal 등, 1984), 이외에도 반추위내 혐기성 미생물의 수와 섬유소 분해 미생물의 수를 증 가시키고(Kumar 등, 1997; El Hassan 등, 1996), 반추위내 혐기도를 높여 이상 발효 억제, $\mathrm{pH}$ 안정, lactate 생성량 감소 등에 의해 미생물의 증식이 활발해지고 미생물 균체 단백질 합성량 이 증가된다(Wallace, 1994). 이와 같이 yeast는

본 연구는 2001년도 한국학술진흥재단의 대학부설연구소 지원과제(KRF-01-005-G20007)로 수행된 연구결과임. Corresponding author : Jong-Suh, Shin, Division of Animal Resource, Kangwon National University, Chuncheon, 200-701, Korea, Tel : 033-250-8628. 
반추가축의 생산성에 미치는 효과가 다양함에 도 불구하고 현재까지의 이용방법은 주로 단순 히 사료에 첨가하는 수준에 머물러 있는 실정 이며, 일부 연구자들(신 등, 1994a,b; 박 등, 2003; 박 등, 2003; 임 등, 2001)은 발효사료의 균주로 이용하여 생산성 증진의 효과가 일부 인정된 바 있으나, 아직도 많은 연구가 필요한 실정이다.

사료가격이 높아짐에 따라 식품산업에서 발 생하는 각종 부산물들을 가축의 사료로 이용하 고자하는 노력이 경주되고 있으며, 특히 맥주 제조공정에서 발생하는 맥주박을 기호성 및 사 료가치를 증진시킬 목적으로 반추가축의 사료 자원으로 활용하기 위한 발효공법이 최근 시도 되고 있다. 이와 같은 발효과정에서 alcohol, lactate, acetate, butyrate 등의 발효산물들이 생성 되며(川西 등, 1989; 高野 등, 1982; 鵜創와 堀 內, 1981), 미생물균주 역시 반추가축의 영양소 원으로 이용될 수 있는 부수적인 효과도 얻을 수 있다. 또 다른 연구에 의하면 송아지 이유 사료로 소맥 전분박 및 감자박(액상 부산물)을 발효사료로 제조할 경우 lactate, acetate 및 alco$\mathrm{hol}$ 의 함량은 각각 $3.8 \sim 10.5,0.4 \sim 3.5 \%$ 및 0.1 $\sim 1 \%$ 이었으며, 발효사료중의 젖산균은 2.8 에 서 $9.6 \log \mathrm{cfu} / \mathrm{g}$ 로 증가하고, yeast의 수는 4.3 에서 $6.0 \log \mathrm{cfu} / \mathrm{g}$ 로 증가하며, $\mathrm{pH}$ 는 $3.5 \sim 4.2$ 로 유기산뿐만 아니라 알코올, $\mathrm{pH}$ 및 균체에도 변화를 줄 수 있다(Jensen 등, 1998; Mikkelsen 과 Jenson, 1997).

맥주박을 이용한 발효사료의 균주로 yeast 를 이용할 경우 사료의 발효과정에서 alcohol, ammonia $\mathrm{N}$ 및 lactate 등의 발효 산물이 생성되 는데(박, 2002; 임 등, 1999), 이들 발효산물 중 에서도 알코올은 비육우의 일당증체량(박 등, $2003, \mathrm{~b}$; 임 등, 2001; 신 등, 1994b), 사료효율 (박 등, 2003; 신 등, 1994a), 배최장근단면적(박 등, 2003; 박 등, 2003; 신 등, 1994b) 및 근내지 방도(박 등, 2003; 신 등, 1994b)에 영향이 있는 것으로 알려져 있다.

그러나 가축의 생균제 혹은 발효사료의 균주 로 활용되고 있는 yeast의 경우 발효기질로 전 분 및 섬유소의 이용성은 제한적인 반면에 단
당류 및 2당류(glucose, fructose 및 sucrose 등) 를 이용하는 특성이 있다. 따라서 맥주제조 과 정에서 malting, mashing, filteration 및 효소적인 분해 등의 공정으로 인해 맥주박내의 당조성이 변하여 yeast가 쉽게 이용할 수 없기 때문에 당 밀과 같은 원료의 추가적인 첨가가 필요하나, 최적 발효를 위한 최적 첨가수준에 관하여는 확실하게 구명되어 있지 않다. 한편 맥주박 발 효사료의 제조를 위한 yeast의 첨가수준과 yeast 가 사료내의 당을 이용하여 최적의 발효과정을 통해 알코올을 생성할 수 있는 발효조건(발효 온도 및 시간)도 중요한 요인으로 작용한다. 그 러나 아직까지 맥주박을 이용하여 알코올 발효 사료를 제조하는 과정에서 연구자들에 따라 당 밀의 첨가수준, yeast의 첨가 수준, 발효 온도 및 발효시간이 다른 실정이므로 반추가축을 대 상으로 맥주박에 yeast를 이용하여 제조하는 알 코올 발효사료의 이용에 있어서 문제점으로 지 적되어 왔다.

따라서 본 시험은 발효공법을 통해 맥주박에 yeast를 이용한 알코올 발효사료를 제조하는데 있어서 최적을 발효조건을 결정하기 위해 당밀 의 첨가수준, yeast의 첨가 수준 및 발효 온도 에 따른 발효특성 및 사료적 가치를 조사하여 맥주박 알코올 발효사료를 제조하는데 최적의 발효조건을 도출하기 위하여 실시하였다.

\section{II. 재료 및 방법}

\section{1. 시험설계 및 시험사료 제조}

본 시험에 이용한 맥주박 알코올 발효를 위 한 기초사료는 맥주박과 파쇄 옥수수를 50:50 (풍건상태)의 비율로 혼합한 후 당과 live yeast (saccharomyces cerevisiae, 이하 Yeast)를 첨가하 여 제조하였다. 시험의 목적에 따라 발효사료 제조 시 당밀 첨가 수준, yeast 첨가 수준, 발효 온도 및 발효시간을 각각 달리하여 발효특성을 조사하였다. 우선 당밀의 첨가수준이 사료내 알코올의 생성량에 미치는 효과를 조사하기 위 한 시험에서는 맥주박과 파쇄 옥수수의 비율, yeast의 첨가량 $(2 \%)$, 발효온도 $\left(30{ }^{\circ} \mathrm{C}\right)$ 및 발효시 
간(24시간)은 동일한 조건하에서 당밀의 첨가수 준을 각각 0,2 및 $5 \%$ 로 달리하여 적정 당밀 의 첨가 수준을 결정하였다. Yeast 첨가수준 결 정 시험은 당밀첨가수준 시험에서 결정된 당밀 첨가수준, 발효온도 $\left(30{ }^{\circ} \mathrm{C}\right)$, 발효시간(48시간)은 동일한 조건하에서 yeast의 첨가 수준을 0.1 , $0.5,1$ 및 $2 \%$ 로 달리하여 사료중의 알코올 함 량 및 yeast cell number $(\mathrm{LYCN})$ 를 조사하였다. 마지막으로 당밀 첨가수준에 관한 시험에서 결 정된 당밀 첨가수준, yeast 첨가수준에 관한 시 험에서 결정된 yeast 첨가수준 및 발효시간은 동일한 조건하에서 발효온도를 각각 $4,10,30$, 40 및 $50{ }^{\circ} \mathrm{C}$ 로 달리하여 사료중의 알코올 함량 및 $\mathrm{pH}$ 변화를 조사하였다. 본 시험에 이용한 시험사료의 일반 화학성분은 Table 1에서 나타 낸 바와 같다.

Table 1. Chemical composition of experimental diets of wet brewer's grains and cracked corn

\begin{tabular}{lcc}
\hline & $\begin{array}{c}\text { Wet brewer's } \\
\text { grains }\end{array}$ & $\begin{array}{c}\text { Cracked } \\
\text { corn }\end{array}$ \\
\hline \hline Dry matter, \% & $25.8 \pm 0.2$ & $88.6 \pm 0.2$ \\
& $\ldots . . . \%$ of dry & matter $\cdots . .$. \\
Crude protein, \% & $24.3 \pm 0.2$ & $10.4 \pm 0.3$ \\
Ether extract, \% & $8.8 \pm 0.4$ & $4.6 \pm 0.4$ \\
Crude fiber, \% & $19.1 \pm 0.6$ & $3.5 \pm 0.1$ \\
Crude ash, \% & $1.3 \pm 0.1$ & $3.4 \pm 0.1$ \\
Nitrogen free extract, \% & 46.5 & 78.2 \\
Neutral detergent fiber, \% & $77.8 \pm 3.1$ & - \\
Acid detergent fiber, \% & $27.4 \pm 0.4$ & - \\
Acid detergent lignin, \% & $5.2 \pm 0.1$ & - \\
\hline
\end{tabular}

\section{2. 분석항목 및 분석방법}

(1) 알코올 농도

당밀 첨가수준별 알코올 함량은 발효 24시간 후에 측정하였으며, yeast 첨가수준 및 온도별 알코올 함량 변화는 발효개시전(0시간) 및 48시 간까지 3 시간 간격으로 시료를 채취하여 측정 하였는데, 알코올 함량은 채취한 시료를 증류
수로 5 배 희석하여 vortex mixer로 충분히 혼합 한 후 $4{ }^{\circ} \mathrm{C}$ 냉장고에서 30 분간 방치하였으며, $3,000 \mathrm{rpm}$ 에서 5 분간 원심분리하여 상층액을 분 리한 후 glucose analyzer (YSI 2700, USA)를 이 용하여 분석하였다.

\section{(2) Dextrose 농도}

시간대별로 채취한 시료를 buffer solution $(40 \mathrm{~g} / 1$ $\mathrm{NaH}_{2} \mathrm{PO}_{4}, \quad 10 \mathrm{~g} / \mathrm{l} \quad \mathrm{Na}_{2} \mathrm{HPO}_{4}$ )으로 5 배 희석하여 vortex mixer로 충분히 혼합하여 $4{ }^{\circ} \mathrm{C}$ 냉장고에 30 분간 방치한 후 $2,000 \mathrm{rpm}$ 에서 5 분간 원심분리 하여 상층액을 취하고 glucose analyzer(YSI2700, USA)를 이용하여 dextrose 함량을 측정하였다.

\section{(3) yeast cell number 변화}

발효과정 중 yeast 첨가 수준별 생균수(yeast cell number; LYCN) 변화를 알아보기 위하여 발효개시전(0시간)과 발효 48 시간에 채취한 $1 \mathrm{~g}$ 의 시료를 증류수로 40배 희석한 후 methylene blue dihydrate(1:5000)로 생사판별염색(相田 등, 1982)을 실시하고 Hemocytometer를 이용하여 400 배 현미경하에서 5 개 구역의 생균수를 측정 하였다. 생균수 측정에 이용한 공식은 다음과 같다.

생균수(live cells/g) =

(계측생균수 $\times 5 \times 104 \times$ 희석배율) / 시료무게 $(\mathrm{g})$

(4) $\mathrm{pH}$ 측정

시험사료는 온도별로 48 시간동안 발효시키면 서 발효개시전(0시간)부터 발효 48시간까지 3시 간 간격으로 시료를 채취하여 $\mathrm{pH}$ 변화를 측정 하였는데, $\mathrm{pH}$ 측정은 시간대별로 채취한 시료 를 증류수로 5 배 희석하여 vortex mixer로 충분 히 혼합한 후 $4{ }^{\circ} \mathrm{C}$ 냉장고에서 30 분간 방치하 였으며, $3,000 \mathrm{rpm}$ 에서 5 분간 원심분리하여 상 층액을 분리한 후 $\mathrm{pH} \operatorname{meter}(\mathrm{CORNING} 445$, $\mathrm{USA}$ )를 이용하여 $\mathrm{pH}$ 를 측정하였다.

\section{3. 통계분석}

본 시험에서 얻은 결과들은 $\mathrm{SAS}(1995)$ 통계 package를 이용하여 GLM/Duncan의 방법으로 처 
리간의 유의성을 검증하였고, 발효시간에 대한 발 효산물들의 함량 변화추세를 알아보기 위하여 비 선형 회귀곡선식을 추정하였다. 처리간의 유의성 검증을 위해 적용한 선형방정식은 다음과 같다.

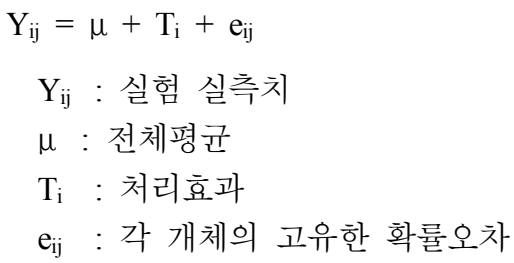

\section{III. 결과 및 고찰}

\section{1. 당밀 첨가수준에 따른 알코올 생성 효과}

yeast를 이용한 맥주박 알코올 발효사료의 발 효 효과를 증진시키기 위한 당밀의 적정 첨가 수준을 규명하기 위해 당밀을 각각 $0,2.0$ 및 $5.0 \%$ 첨가하고 yeast $2 \%$ 를 첨가하여 $30{ }^{\circ} \mathrm{C}$ 의 혐기적인 조건에서 24시간 동안 발효한 후 알 코올 생성량을 측정한 결과는 Fig. 1 과 같다. 당밀 첨가수준이 $0,2.0$ 및 $5.0 \%$ 일 때 알코올 함량은 각각 $1.1,2.6$ 및 $3.2 \%$ 로 당밀 첨가수 준이 증가할수록 알코올 생성량이 유의적으로 증가하였다 $(\mathrm{P}<0.05)$. 이와 같은 결과는 당밀 이 $50 \%$ 이상의 당분을 함유하고 있을 뿐만 아니라(한 등, 1994) 혐기적인 조건하에서 yeast가 알코올 생성을 위해 쉽게 이용할 수 있는 zymohexose인 dextrose 함량이 $16.4 \%$ 정 도로 알코올 발효사료의 주원료인 맥주박 $(0.05 \%)$ 및 파쇄 옥수수 $(0.4 \%)$ 에 비해 상대적으로 dextrose 함량이 높기 때문에(Fig. 2) 당밀의 첨가 수준에 비례하여 알코올의 생성량이 증가한 것 으로 판단된다. 또한 맥주박의 가용성 탄수화 물은 주로 pentosan으로 구성되어 있으며 파쇄 옥수수의 경우에는 주로 전분으로 구성되어 있 기 때문에(한 등, 1994), 맥주박 및 파쇄 옥수수 로부터 yeast가 알코올을 생성하기에는 부적합 한 구조라 할 수 있다. 따라서 맥주박 알코올 발효사료의 알코올 생성은 주로 당밀에 의존하 는 것으로 볼 수 있으나, 당밀 무첨가구도 $1 \%$ 정도의 알코올이 생성되는 것으로 미루어 맥주
박 알코올 발효사료의 알코올 생성은 전적으로 당밀에만 의존하지는 않는 것으로 생각된다. 즉, malting 과정을 거친 맥주박은 전분의 $40 \%$ 정도가 소비되고, 나머지는 pentosan으로 존재 하며, 일부 당화 효소가 잔류하는 것으로 알려 져 있다(NRC, 1988, Polan 등, 1985). 또한 yeast 배양 후에 잔존하게 되는 yeast 사체의 경우 glucose, lactate, malate, formate, succinate 및 aspartate 등을 함유(Callaway와 Martin, 1997)하 고 있을 뿐만 아니라, 맥주박내에 잔존하던 yeast 혹은 yeast 사체로부터 유래한 glucose를 이용하여 당밀 무첨가구에서도 일부 알코올이 생성되며, 또한 malting 과정에서 맥주박에 약간 잔존하였던 당화 효소에 의해서도 옥수수 전분 의 일부가 당화되어 알코올 생성을 위해 사용되 었을 가능성도 있는 것으로 사료된다. 이외에도 맥주박의 저장 및 운송과정에서 amylase 및 xylanase 등의 효소활성이 우수하여(Petterson 등, 1989) 유기성 물질의 분해가 가능한 Aspergillus niger 혹은 Aspergillus oryzae 등과 같은 호기성 곰팡이(Garraway와 Evans, 1984)의 유입이나, 자 연적으로 맥주박 및 옥수수에 존재하지만 yeast 에 의한 이용성이 떨어지는 탄수화물의 일부가 dextrose 형태로 변화되어 알코올로 전환되었을 것으로 생각되지만, 본 실험의 결과만으로 결 론을 내리는 데에는 한계가 있다.

Fig. 1. Effect of molasses supplementation level on alcohol concentrations in alcoholfermented feeds with wet brewer's grains. Values are means, and vertical bars represent standard deviations.

Values with different letters are significantly different $(\mathrm{P}<0.05)$. 
Fig. 2. Dextrose concentrations in wet brewer's grains, corn meal, and molasses.

Values with different letters are significantly $\operatorname{different}(\mathrm{P}<0.05)$.

2. yeast 첨가수준에 따른 알코올 및 yeast cell number 변화

당밀 첨가수준에 따른 알코올 생성 효과를 검토하기 위한 시험에서 알코올 생성량이 가장 높은 당밀 첨가 수준이 $5.0 \%$ 로 나타난 결과를 토대로 yeast의 첨가 수준 $(0.1,0.5,1.0$ 및 $2.0 \%)$ 에 따른 알코올 생성량 및 yeast cell number $(\mathrm{LYCN})$ 의 변화를 검토하고자 하였다(Fig. 3 및 4). Yeast의 첨가 수준에 관계없이 시험사료 중 의 알코올 함량은 발효시간이 경과함에 따라 24 시간까지 급속히 증가하는 것으로 나타났으 나, yeast 0.1 및 $0.5 \%$ 구에 비해 1.0 및 $2.0 \%$ 첨가구가 발효시간에 관계없이 알코올 생성량 이 상대적으로 높았다 $(\mathrm{P}<0.05)$. 발효 24시간에 yeast $0.1,0.5,1.0$ 및 $2.0 \%$ 구의 알코올 함량은 각각 $1.9,2.4,3.1$ 및 $3.1 \%$ 로 나타나 yeast 첨가 수준 $1 \%$ 까지는 yeast의 첨가수준이 증가할수 록 시험사료중의 알코올 생성량도 비례적으로 증가하는 결과를 얻었으나 $(\mathrm{P}<0.05)$, yeast 첨가 수준 1.0 및 $2.0 \%$ 구간에는 알코올 함량의 차 이가 없는 것으로 나타났다. 또한 yeast 첨가수 준 1.0 및 $2.0 \%$ 구의 경우 동일한 지수함수로 표시할 수 있는 것으로 미루어 본 시험의 조건 하에서 시험사료중의 알코올 생성량을 최대로 할 수 있는 최적 yeast 첨가수준은 $1 \%$ 인 것으 로 판단된다 $(\mathrm{Y} 1,2 \%=3.23-3.12 \mathrm{e}-0.09 \mathrm{t})$.

Yeast의 첨가수준에 따른 사료중의 $\mathrm{LYCN}$ 의 변화를 조사한 결과, 발효 0시간의 경우 yeast
Fig. 3. Effect of yeast supplementation levels on alcohol concentrations in the alcoholfermented feeds.

$\mathrm{Y}$ : Alcohol production rate. $\mathrm{T}$ : Fermentation time.

Fig. 4. Effect of yeast supplementation levels on live yeast cell numbers in the alcoholfermented feeds with wet brewer's grains.

Values with different letters are significantly different $(\mathrm{P}<0.05)$

* Significant differences from 0 time group at the same treatment $(\mathrm{P}<0.05)$.

첨가수준이 증가할수록 $\mathrm{LYCN}$ 이 증가하는 결 과를 보였다. 그러나 발효 48 시간에 $0.1,0.5$, 1.0 및 $2.0 \%$ 구의 $\mathrm{LYCN}$ 은 각각 $4.4,5.6,5.8$ 및 $6.1 \times 108$ cells $/ \mathrm{g}$ 로 나타나, $0.5,1.0$ 및 $2.0 \%$ 첨가 수준에서는 $\mathrm{LYCN}$ 의 차이를 보이지 않은 반면에 $0.1 \%$ 첨가 수준에서 $\mathrm{LYCN}$ 이 유의적으 로 낮게 나타났다 $(\mathrm{P}<0.05)$. 이는 발효시간이 경과함에 따라 yeast가 알코올 생성 및 증식을 위해 이용할 수 있는 당의 고갈에 일차적인 원 인이 있는 것으로 판단된다. 박(2002)은 본 실 험의 $1.0 \%$ 구와 동일한 조건하에서 발효시간에 따른 dextrose 함량 변화를 조사한 결과 발효 6 
시간까지 사료중의 dextrose 함량이 급격히 감 소하여 발효 48시간까지 낮은 농도를 일정하게 유지했다고 보고하였는데, 이는 발효초기에 yeast가 이용할 수 있는 당이 급격히 소실되어 $\mathrm{LYCN}$ 이 더 이상 증가하지 않을 가능성을 시사 하는 것이다. 또한 $\operatorname{Cassio(1987)ㄴㅡㄴ~ㅂㅏㄹㅎㅛㄱㅘㅈㅓㅇㅇㅔㅅㅓ~}$ 당분의 충분한 공급은 지속적인 yeast의 성장을 가능하게 한다고 보고하여 $\mathrm{LYCN}$ 이 당분의 고 갈과 밀접한 관계가 있음을 시사한 바 있다.

한편, 사료의 발효과정에서 생성되는 발효산 물(알코올, acetate 및 젖산 등) 또한 yeast의 증 식을 억제하는 요인으로 작용하는 것으로 판단 된다. 박(2002)은 본 실험의 $0.1 \%$ 구와 동일한 조건하에서 발효 48 시간에는 $2.31 \%$ 의 젖산이 생 성되었다고 보고하여 사료중의 젖산이 $\mathrm{LYCN}$ 에 영향을 미칠 수 있음을 시사한 바 있다. 또한 高 野 등(1982)도 미생물을 이용한 사료의 발효과정 에서 알코올, acetate, butyrate 및 lactate 등이 발 효산물로 생성되는 것으로 보고한 바 있다. 이외 에도 今#ㅠ 등(1996)은 비지박을 plastic drum can 에 밀폐하여 4일간 발효시켰을 경우 yeast 균은 $103 \mathrm{cell} / \mathrm{g}$ 이하로 저하되지만 젖산균은 $1.5 \times 108$ cell / g로 증가하였다고 보고하여 비록 본 실험에 서 사료중의 lactate 함량을 조사하지는 않았으나, 사료의 발효과정에서 생성된 lactate 역시 $\mathrm{LYCN}$ 에 영향을 미쳤을 것으로 사료된다. 따라서 30 ${ }^{\circ} \mathrm{C}$ 의 혐기적인 조건에서 $\mathrm{LYCN}$ 만을 고려한다면 맥주박 알코올 발효사료에 대한 yeast의 첨가수 준은 $0.5 \%$ 이상이 바람직한 것으로 사료된다.

\section{3. 발효온도 및 발효시간에 따른 발효특성의 변화}

적정 당밀 및 yeast 첨가수준에 관한 결과를 근거로 하여 당밀 $5 \%$ 및 yeast $1 \%$ 를 첨가하 는 조건하에서 발효온도가 알코올 발효사료의 알코올 함량 및 사료의 $\mathrm{pH}$ 변화에 미치는 영 향을 조사한 결과는 Fig. 5 및 6에 나타낸 바와 같다. 본 시험의 조건하에서 발효 온도별 알코 올 함량은 발효 온도 $4{ }^{\circ} \mathrm{C}$ 에서는 발효시간에 관계없이 알코올 생성이 억제되는 것으로 나타 났으나, 발효 온도 $10{ }^{\circ} \mathrm{C}$ 에서는 발효 12시간까
지는 알코올의 생성이 억제되었지만 그 이후 발효시간이 경과함에 따라 알코올이 생성되었 다. 또한 발효 온도 $50{ }^{\circ} \mathrm{C}$ 에서는 발효 6시간까지 는 알코올의 생성이 원활하게 이루어졌으나 이 후 발효시간에는 더 이상의 알코올 생성이 이루 어지지 않아 24 시간 이후에는 발효온도 $10{ }^{\circ} \mathrm{C}$ 의 결과와 차이가 없는 것으로 나타났다. 한편, 발 효 온도 30 및 $40{ }^{\circ} \mathrm{C}$ 의 경우에는 발효 6 시간까 지 알코올이 급격하게 생성되어졌으며 $(2.82 \mathrm{vs}$ $2.53 \%$ ), 발효 12 시간에 알코올 생성량이 최대 에 도달하여(3.18 vs $2.75 \%)$, 이후 일정하게 유 지되었다. 따라서 발효초기에 알코올의 생성이 원활하게 이루어짐과 동시에 전체적으로 알코 올 생성이 $30{ }^{\circ} \mathrm{C}$ 에서 가장 높게 나타난 점으로 미루어 맥주박 알코올 발효사료의 적정 발효 온도는 $30{ }^{\circ} \mathrm{C}$ 인 것으로 판단되는데, 이는 순수 알코올 발효공정에서 적용되는 발효온도(김 등, 1994)와도 동일한 조건이다.

Fig. 5. Effect of fermentation temperatures on alcohol concentrations in alcohol-fermented feedstuff with brewer's grains.

Fig. 6. Effect of fermentation temperatures on the $\mathrm{pH}$ of alcohol-fermented feeds with brewer's grains. 
한편, 발효온도에 따른 시험사료들의 $\mathrm{pH}$ 변 화를 살펴보면, 발효온도 4 및 $10{ }^{\circ} \mathrm{C}$ 구가 발효 온도 30,40 및 $50{ }^{\circ} \mathrm{C}$ 구에 비해 발효 24시간까 지 $\mathrm{pH}$ 가 급격히 감소하는 것으로 나타났다 $(\mathrm{P}<$ 0.05). 이와 같은 결과는 $30^{\circ} \mathrm{C}$ 이상의 온도에서 는 정상적인 알코올 발효가 이루어진 반면에 4 및 $10{ }^{\circ} \mathrm{C}$ 에서는 알코올 발효보다는 젖산발효가 이루어지고 있음을 의미한다. 특히, 발효 온도 $4{ }^{\circ} \mathrm{C}$ 에서는 알코올이 전혀 생성되지 않은 점 (Fig. 5)으로 미루어 yeast에 의한 알코올 발효보 다는 저온에서도 증식이 가능한 젖산 생성 미생 물 혹은 잡균에 의한 산성발효가 좀더 우세하게 이루어지고 있음을 짐작할 수 있다. 따라서 발 효 초기에 원활한 알코올 발효를 유도하기 위해 서는 발효초기에 온도를 적정수준 $\left(30{ }^{\circ} \mathrm{C}\right)$ 으로 조 절해주는 것이 바람직한 것으로 판단된다.

\section{IV. 요 약}

본 시험은 맥주박의 알코올 발효가 발효특성 및 사료의 영양적 가치에 미치는 영향을 검토 하기 위하여 실시하였다. 본 시험에 이용한 시 험사료는 맥주박과 파쇄 옥수수를 $50: 50$ (풍건 상태)의 비율로 혼합하여 혐기 발효에 의하여 발효사료를 제조하였다. 발효 조건은 당밀 첨 가 수준 $(0,2$ 및 $5 \%)$, yeast 첨가 수준 $(0,0.1$, $0.5,1.0$ 및 $2.0 \%)$ 및 발효 온도 $(4,10,30,40$ 및 $\left.50{ }^{\circ} \mathrm{C}\right)$ 에 따른 변화를 검토하였으며, 각 조 건에 의한 알코올 함량, live yeast cell number $(\mathrm{LYCN})$ 및 $\mathrm{pH}$ 변화를 조사하였다.

당밀 첨가에 따른 알코올 함량은 첨가수준이 증가할수록 높게 생성되었다. 발효 24시간 동 안에 yeast $0.1,0.5,1.0$ 및 $2.0 \%$ 첨가에 따른 알코올 함량은 각각 $1.9,2.4,3.1$ 및 $3.1 \%$ 로 나 타나, yeast 첨가수준 $1 \%$ 까지는 yeast의 첨가 수준이 증가할수록 시험사료중의 알코올 생성 량도 비례적으로 증가하였으나 $(\mathrm{P}<0.05)$, yeast 첨가수준 1.0 이상에서는 일정한 양의 알코올 이 생성되었다. 발효 초기의 $\mathrm{LYCN}$ 은 yeast 첨 가수준이 높을수록 높게 나타났으나 $(\mathrm{P}<0.05)$, 발효 48 시간 후의 $\mathrm{LNCN}$ 은 $0.1 \%$ 이하에서는 유의적으로 낮게 나타났다 $(\mathrm{P}<0.05)$.
발효 온도에 따른 알코올 생성량은 발효 온 도 30 및 $40{ }^{\circ} \mathrm{C}$ 에서 유의적으로 높은 결과를 보였으며 $(\mathrm{P}<0.05), 30{ }^{\circ} \mathrm{C}$ 와 $40{ }^{\circ} \mathrm{C}$ 간의 알코올 생성량은 $30{ }^{\circ} \mathrm{C}$ 에서 높은 경향이었다. 발효 온 도에 따른 $\mathrm{pH}$ 는 발효 온도가 낮을수록 발효 24 시간까지 급격히 감소하는 것으로 나타났다 $(\mathrm{P}<0.05)$.

이상의 결과로 미루어 맥주박의 사료적 가치 를 높이기 위해 yeast의 첨가량, 당밀(발효기질), 발효온도 및 발효시간 등의 요인을 고려하였을 경우, 본 시험의 조건하에서 원활한 알코올 발 효와 발효사료의 품질을 향상시키기 위한 적정 발효조건은 당밀 $5 \%$ 와 yeast $1 \%$ 를 첨가하여 $30{ }^{\circ} \mathrm{C}$ 에서 24 시간 동안 발효시키는 것이 가장 바람직한 것으로 나타났다.

\section{$\mathrm{V}$. 인 용 문 헌}

1. Callaway, E. S. and Martin, S. A. 1997. Effects of a Saccharomyces cerevisiae culture on ruminal bacteria that utilize lactate and digest cellulose. J. Dairy Sci. 80:2035-2044.

2. Cassio, F., Leao, C. and van Uden, N. 1987. Applied and Environmental, Microbiology. 53:509513.

3. El Hassan, S. M., Newbold, C. J., Edwards, I. E., Topps, J. H. and Wassace, J. R. 1996. Effect of yeast culture on rumen fermentation, microbial protein flow from the rumen and live-weight gain in bulls given high-cereal diets. Anim. Sci. 62:43-48.

4. Fallon, R. J. and Harte, F. J. 1987. The effect of yeast culture inclusion in the concentrate diet on calf performance. J. Dairy Sci. 70(Suppl.) 1:143 (Abstr.).

5. García, C. C. G., Mendoza, M. G. D., González, M. S., Cobos, P. M., Ortega, C. M. E. and Ramirez, L. R. 2000. Effect of a yeast culture(Saccharomyces cerevisiae) and monensin on ruminal fermentation and digestion in sheep. Anim. Feed Sci. and Technology 83(200):165-170.

6. Garraway, M. O. and Evans, R. C. 1984. Fungal nutrition and physiology. John Wiley \& Sons, Inc., New York.

7. Jensen, M. S., Thaela, M. J., Pierzynowski, S. G., Jakob, S. and Jensen, B. B. 1998. Effect of lactic acid supplementation on pancreatic secretion in pigs 
after weaning. J. Anim. Feed Sci. 7(suppl.1):181-183.

8. Kumar, U., Sareen, V. K. and Singh, S. 1997. Effect of yeast culture supplement on ruminal microbial populations and metabolism in buffalo calves fed a high roughage diet. J. Sci Food Agric. 73:231-236.

9. Mikkelsen, L. L. and Jensen, B. B. 1997. Effect of fermented liquid feed(FLF) on growth performance and microbial activity in the gastrointestinal tract of weaned piglets. In : Laplace, J. P., Fevrier, Barbeau, A.(Eds.), Digestive Physiology in Pigs. E. A. A. P. publication No. 88:26-28 May. Saint Malo, France. pp. 639-642.

10. Newbold, C. J., Mclntosh, F. M. and Wallace, R. J. 1998. Changes in the microbial population of a rumen simulating fermenter in response to yeast culture. Can. J. Anim. Sci. 78:241-244.

11. NRC. 1988. Nutrient requirements of dairy cattle. 6th Rev. Natl. Acad. Washington.

12. Panchal, C. J., Russell, L., sills, A. M. and Stewart, G. G. 1984. Genetic manipulation of brewing and related yeast strains. Food Technol. 99:111.

13. Pettersson, D., Graham, H. and Amen, P. 1989. Enzyme supplementation of broiler chickens. Anim. Prod. 51:399-404.

14. Polan, C. E., Herrington, T. A., Wark, W. A. and Armentano, L. E. 1985. Milk production response to diets supplemented with dried brewers grains, wet brewer's grains, or soybean meal. J. Dairy Sci. 68:2016.

15. SAS ${ }^{\circledR}$ User's guide: Statistics, Version 5 Edition. 1985. SAS Inst., Inc., Cary, NC.

16. Sullivan. H. M. and Martin, S. A. 1999. Effects of a Saccharomyces cerevisiae culture on in vitro mixed ruminal microorganism Fermentation. J. Dairy Sci. 82:2011-2016.

17. Wallace, R. J. 1994. Ruminal microbiology, biotechnology, and ruminant nutrition: progress and problems. J. Anim. Sci. 72:2992-3003.

18. Wang Z., Eastridge, M. L. and Qiu, X. 2001. Effects of forage neutral detergent fiber and yeast culture on performance of cows during early lactation1. J. Dairy Sci. 84:204-212.

19. Williams, P. E. V., Tait, C. A. G., Innes, G. M. and Newbold, C. J. 1991. Effects of the inclusion of yeast culture (Saccharomyces cerevisiae plus growth medium) in the diet of cows on milk yield and forage degradation and fermentation patterns in the rumen of sheep and steers. J. Anim. Sci. 69:3016-3026.
20. Wohlt, J. E., Corcione, T. T. and Zajac, P. K. 1998. Effect of yeast on feed intake and performance of cows fed diets based on corn silage during early lactation. J. Dairy. Sci. 81:1345-1352.

21. 高野信雄 1982. 壓搾生醬油粕を用いた高水分 silage. 畜産の研究 第36卷 第11号. pp. 1349-1352.

22. 今井明夫. 1996. 豆腐粕混合飼料による乳用去勢 牛の低 cost 肥育法, 畜産の研究 第 50 卷 第 4 号. pp. 487-491.

23. 相田德二郎, 等. 1982. 微生物學實驗法. 微生物研 究法懇談會編. 講談社. p. 202.

24. 鵜創信義, 堀內 勳. 1981. 未利用資源の飼料化と その 實際(續報 2), 畜産の研究 第35怣 第8号. pp. 1003-1007.

25. 川西隆智. 1989. 豆腐粕醱酵飼料の肉用繁殖牛一 の給與. 畜産の研究 第43卷 第12号. pp. 1374-1376.

26. 김찬작, 김교창, 김도영, 오만진, 이석건, 이수오. 정순택, 정지흔. 1994. 발효공학. 선진문화사.

27. 박병기, 길준민, 김종복, 홍병주, 라창식, 신종서. 2003. 맥주박 발효사료 및 대두의 급여가 한우 거세우의 육성 성적 및 도체등급에 미치는 영향. 한국동물자원지. 45(3):397-408.

28. 박병기, 홍병주, 신종서. 2003. Saccharomyces cerevisiae를 첨가한 발효사료의 급여가 한우 비거세 우의 육성성적 및 도체 등급에 미치는 영향. 한 국동물자원지. 45(3):409-420.

29. 박병기. 2002. Aspergillus oryzae 및 Saccharomyces cerevisiae를 처리한 발효사료의 가치 평가 및 반 추위내 미생물 변화에 미치는 영향. 강원대학교 대학원 석사학위논문.

30. 신종서, 김종복, 성경일, 여인서, 김기은, 홍병주. 1994. 고품질 쇠고기 생산을 위한 한우 사육기술. 2. 소 성장호르몬과 알코올발효사료의 처리가 도 체품질 및 조성에 미치는 영향. 한영사지. 18(5): 373-381.

31. 신종서, 김종복, 성경일, 여인서, 김기은, 박연수, 홍병주. 1994. 고품질 쇠고기 생산을 위한 한우 사육기술. 1. 소 성장호르몬과 알코올발효사료의 처리가 증체율, 사료효율, 혈액성상, 육조성 및 도체등급에 미치는 영향. 한영사지. 18(5):363-372.

32. 임광철, 김창혁, 오상집, 성경일, 김현숙, 김종복, 홍병주, 신종서. 2001. 알코올발효사료 급여가 한 우의 육성성적 및 혈액의 생리적 변화에 미치는 영향. 동물자원과학회지. 43(6):881-894.

33. 임광철, 라창식, 고용균, 오진석, 홍병주, 신종서. 1999. 비지박 및 맥주박 알코올 발효사료의 in vitro 발효특성. 동물자원연구. 10:157-166.

34. 한인규. 1994. 사료자원핸드북, 제3판. p. 254.

(접수일자 : 2005. 5. 17. / 채택일자 : 2005. 7. 4.) 